
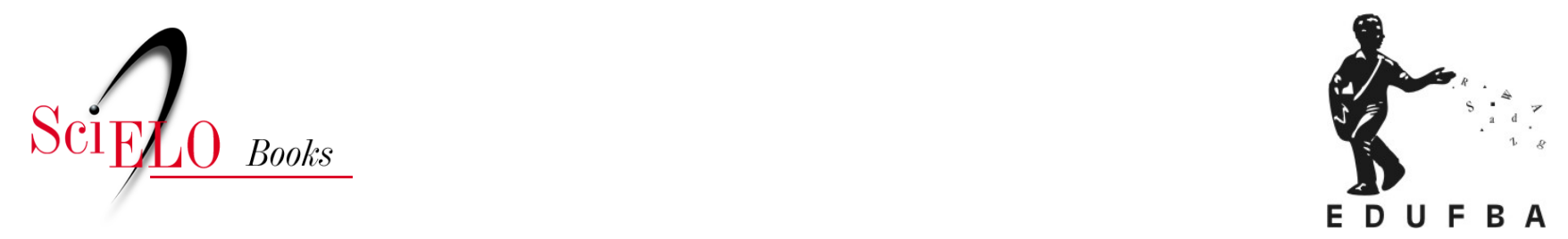

\title{
A Apoteose da Imaculada \\ um estudo iconográfico e compositivo sobre a pintura do teto da nave da Igreja de Nossa Senhora da Conceição da Praia
}

\author{
Mônica Farias Menezes Vicente
}

\section{SciELO Books / SciELO Livros / SciELO Libros}

VICENTE, M.F.M. A Apoteose da Imaculada: um estudo iconográfico e compositivo sobre a pintura do teto da nave da Igreja de Nossa Senhora da Conceição da Praia. In: HERNÁNDEZ, M.H.O., and LINS, E.Á., eds. Iconografia: pesquisa e aplicação em estudos de Artes Visuais, Arquitetura e Design [online]. Salvador: EDUFBA, 2016, pp. 40-69. ISBN: 978-85-232-1861-4.

https://doi.org/10.7476/9788523218614.0004.

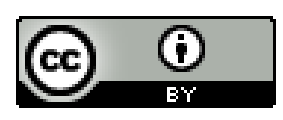

All the contents of this work, except where otherwise noted, is licensed under a Creative Commons Attribution $\underline{4.0 \text { International license. }}$

Todo o conteúdo deste trabalho, exceto quando houver ressalva, é publicado sob a licença Creative Commons Atribição 4.0. 
A Apoteoseda

\section{Imaculada: um}

estudo iconográfico

e compositivo sobre

a pintura do teto da

nave da lgreja de

Nossa Senhora da

\section{Conceição da Praia :}

Mônica Farias Menezes Vicente 


\section{Introdução}

culto da Imaculada Conceição de Maria faz parte de antigas e veneráveis tradições, sendo o Brasil um dos grandes patrocinadores dessa veneração.

Se o Brasil nasceu à sombra da Cruz, organizou-se, cresceu, prosperou amparado sempre pela Mãe Santíssima, venerada ternamente e invocada sob numerosos títulos, cada qual mais belo e expressivo... Entre os títulos marianos prevalece o da Imaculada, que exora, com muitos secundários, mais de 350 dos templos principais. E era natural. Desde os primórdios floresceu em Terras de Santa Cruz a devoção à Imaculada Conceição de Maria, implantada pelos descobridores. (PIO XII, 1954 apud SANTOS, 1996, p. 7)

Em honra da santa e indivisa Trindade, para decoro e ornamento da Virgem Mãe de Deus [...], declaramos, pronunciamos e definimos a doutrina que sustenta que a beatíssima Virgem Maria, no primeiro instante de sua conceição, por singular graça e privilégio de Deus onipotente, em vista dos méritos de Jesus Cristo, Salvador do gênero humano, foi 
preservada imune de toda mancha de pecado original, essa doutrina foi revelada por Deus e, portanto, deve ser sólida e constantemente crida por todos os fiéis. (PIO IX, 1854)

A composição plástico-pictórica, presente no teto da nave da Igreja de Nossa Senhora da Conceição da Praia, apresenta um quadro recolocado central cuja cenografia ressalta a Nossa Senhora coroada e entre os reinos celestial e o terreno. Trabalhada nos padrões pictóricos do modelo da falsa arquitetura, quando desenvolvida em Salvador (século XVIII), essa cenografia central está em posição frontal ao espectador que, de baixo, a contempla (Figura 1).

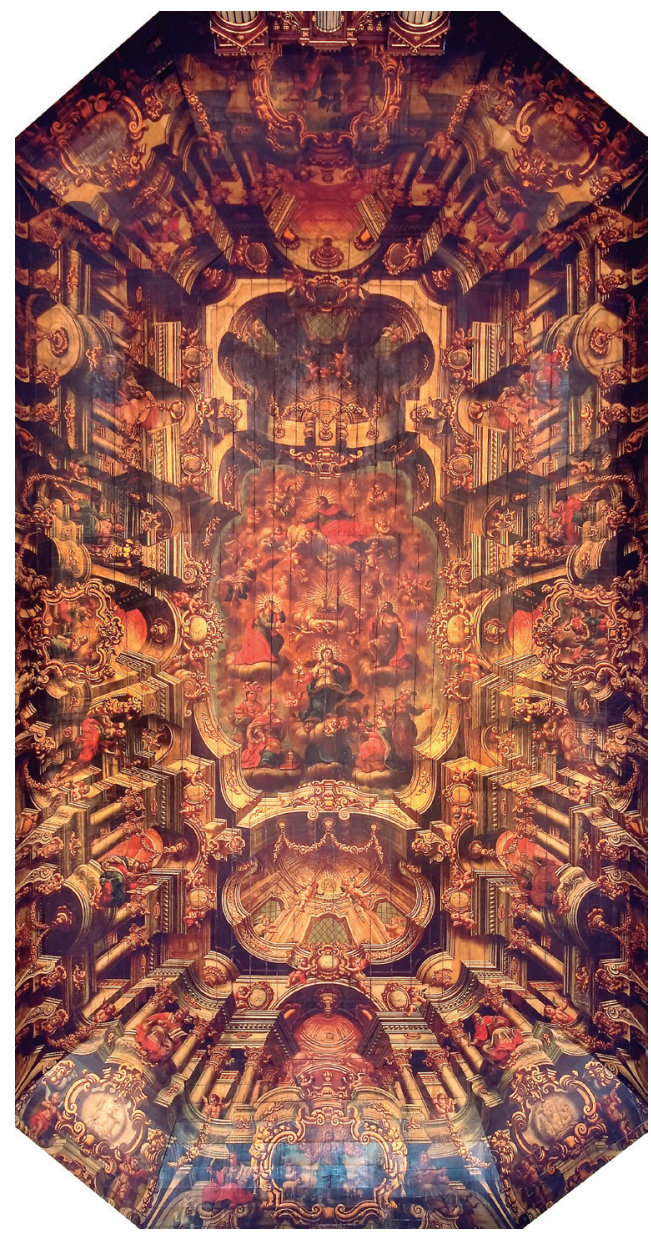

Figura 1 - O prenúncio do Juízo Final pela Santíssima Virgem de José Joaquim da Rocha $(1773-7174)^{1}$ Fotógrafo: Aníbal Gondin.

1 Título reescrito após leitura iconográfica. 
A representação da Imaculada teve seus defensores mais exaltados no início do século XVII pela Europa, com participação popular em defesa do Dogma, e foi repercutida desde os primórdios artístico-pictóricos da arte sacra na Bahia, onde os artistas contratados a mantém no centro da estrutura compositiva, tendo, no seu entorno, outros personagens sacros, elementos simbólicos e decorativos, que fazem parte do repertório cultural de cada região. Com José Joaquim da Rocha, autor da pintura, não seria diferente. Considerando a mobilidade geográfica das iconografias com temas sagrados, ele poderia ter recebido alguma estampa como referência ou a possuir no seu elenco pedagógico. “[...] Al calor de la controversia los pintores recibieron numerosos encargos, siendo por tal motivo la pintura de la Inmaculada uno de los asuntos más repetidos". 2 (CANAL, 2007, p. 110)

Maria foi erguida ao céu; os anjos na alegria cantam a glória do Senhor. A Virgem Maria foi elevada para as núpcias divinas no céu em que o Rei dos reis ocupa um assento constelado de estrela. ${ }^{3}$

Segundo Ponnau (2006, p. 165), a concepção imaculada de Maria e sua Assunção são, talvez, o cristal no qual o eterno transmuta a argila primeira, na qual ele próprio se deixou modelar. "A Assunção de Maria ao Céu, em corpo e alma, é a garantia de que o homem se salvará todo: também o nosso corpo ressuscitará! A Assunção é o penhor seguro de que o homem triunfará da morte". (SECRETARIADO NACIONAL DE LITURGIA, [20--?])

\section{Estudo da análise iconográfica}

A referida cenografia apresenta um grupamento de figuras que se dividem através de uma demarcação ilusória em ambientes religioso e pagão. Essas figuras estão diretamente relacionadas à vida de Maria, sendo ela uma das principais figuras de interlocução da mensagem de Cristo.

No ambiente religioso, estão: a Santíssima Trindade - Pai (Deus), Filho (Jesus) e Espírito Santo (Pomba) -, São João Batista, São João Evangelista, o Cordeiro Santo, o Livro dos 7 Selos e o anjo anunciador. No ambiente pagão, estão figuras femininas personificando os quatro continentes da época (América, África, Europa e Ásia). Em ambos, há a presença de querubins, os pequenos seres espirituais criados por Deus para também servirem de intermédio entre os dois mundos representados, o celestial e o terreno. Alguns elementos simbólicos que compõem a cena estão vinculados aos personagens e reafirmam a mensagem cristã. Os códigos apresentados na pintura estão resguardados na presença destas personificações e possuem funções iconográficas específicas.

2 “[...] No calor das controvérsias os pintores receberam numerosos encargos, e por este motivo a pintura da Imaculada foi um dos assuntos (temática) mais repetidos”.

3 Antífonas da Assunção 1 e 2. In: Vésperas II. Liturgia das Horas. 
Embora não sendo aqui tratada essa pintura na sua totalidade, fazendo uma leitura da cenografia em conjunto (moldura quadraturística e quadro recolocado), observa-se que a grande faixa de perspectiva ilusória tem seus feixes e raios tangenciais direcionados à cena central e, apesar de se tratar de uma construção matemática em sua elaboração gráfica, a existência dessa moldura justifica a presença desse quadro, servindo ainda de anteparo para situar outras figuras, símbolos e cenas religiosas que fazem parte da mensagem oculta presente na referida iconografia.

De volta ao foco da cenografia central, elaborando uma interpretação ascendente, encontram-se, na parte inferior, ambiente pagão e personificações femininas ladeadas à Virgem, duas a duas. Em posição de súplica, constrição, devotamento ou agradecimento, apresentam movimentos corporais de evocação e estão ricamente paramentadas com vestes e elementos decorativos que traduzem o continente que representam.

$\mathrm{Na}$ divisão ilusória dos ambientes, a relação é de 2:1 (dois religiosos e um pagão), e a Imaculada está focada para ser o centro da composição, sendo, na sua cabeça, determinado o centro óptico da cena. Para esse ponto os olhos do observador se dirigem e é nele que assertivamente se posiciona a divisão espacial central horizontal da pintura.

A figuração da Virgem possui uma identidade particular sob o pincel de José Joaquim da Rocha, embora as características específicas à sua iconografia sejam comuns às demais retratações. Nessa pintura, ela veste vestido branco com mangas internas vermelhas. O manto azul, símbolo de pureza, fé, compaixão e águas batismais, possui barras bordadas e enlaça-a, saindo do ombro direito, passando pelas costas e envolvendo a frente de suas pernas. Um véu (maphórion) repousa na cabeça, ocultando seu cabelo, deixando apenas poucos fios à mostra. O corpo está todo coberto por essa indumentária, representando, assim, a modéstia que essa mulher também figura em sua biógrafa história.

A Virgem leva consigo uma coroa emblemática composta por 12 estrelas, um ramo composto por três flores de açucena na mão esquerda e tem, sob a nuvem que a sustenta, a lua em quarto crescente, simbolizando a castidade. A mão direita repousa sobre o peito. Seu posicionamento tem ligação específica na leitura iconográfica do ambiente pagão, assim como no religioso, sendo, como narrado, o elo entre eles.

Sobre a sua cabeça, coroada por estrelas, estão quatro anjos e dois querubins segurando uma nuvem onde se apoia o Livro dos 7 Selos, referencial da grande transformação do Apocalipse. Sobre ele, está sentado o Cordeiro, animal que representa a ressurreição; o sofrimento de Cristo na cruz em nome dos pecados humanos; um cordeiro que toma o lugar dos homens e, por eles, morrerá imolado diante das aflições e erros que causaram. O próprio Cristo, um homem sem pecados, que aceitou receber os pecados da humanidade na intenção de li- 
bertá-los, segundo as leis do seu Pai. O Filho abençoado pelo Espírito de Deus. O Cordeiro resplandece em luz e segura um cajado em forma de cruz; a cruz pastoral, indicando a presença da fé cristã através do "pastoreio" de Jesus - o "Bom Pastor", que conduziu fiéis e salvou almas perdidas. Envolve esse cajado uma faixa, cuja inscrição é a referência ao Agnus Dei.

Exatamente nesse conjunto, composto pelos querubins e Cordeiro, José Joaquim da Rocha demarca o centro geométrico da obra, de onde constitui toda a estrutura pendular verticalizada para posicionar os pontos de fuga determinantes para alçar as tangentes do traçado perspéctico que emoldura a cena central.

Duas figuras importantes e emblemáticas ladeiam o Cordeiro: São João Evangelista e São João Batista, ambos também apoiados sobre nuvens. O primeiro, situado à esquerda, resplandece em um halo de luz, veste túnica azul com manto vermelho sobreposto, tem na mão direita um cálice, enquanto a esquerda aponta com o indicador para cima, em direção à figura do Deus Pai. O segundo, com vestimenta de corte unilateral e em modelo rudimentar, como as que usam os pastores, tem o manto sobreposto apenas no ombro esquerdo, está descalço e segura, com a mão esquerda e rente ao corpo, um cajado em forma de cruz. Essa cruz é semelhante à do Cordeiro e está envolvida por um filactério que se projeta para suas costas e onde se inscreve: "Eis o Cordeiro que retira o pecado do mundo [Ecce Agnus Dei]”. Esse homem também está coroado em luz. Curiosamente ou assertivamente, aponta para a grande cartela que está projetada na quadratura logo atrás dele, cuja temática retrata "A Visitação de Maria a Isabel".

A representação do Espírito Santo na forma da Pomba está entre o conjunto composto pelo Cordeiro, pelo Livro e também pelo Deus Pai. Alça um voo descendente ou posiciona-se em tentativa de escorço projetado pelo artista. Como as demais figuras, está envolvida em um resplendor de luz.

À esquerda da Pomba, e em diagonal a São João Batista, está um arcanjo anunciador. Hierarquicamente representando um anjo adulto, o único da cena, empunha na mão direita uma trombeta, enquanto o dedo indicador da mão esquerda aponta para o Cordeiro sentado sobre o livro, reforçando a mensagem codificada. Traja vestes esvoaçantes, que deixam os seios à mostra, e usa sandálias amarradas às pernas, no estilo greco-romano. ${ }^{4}$

Rodeado por um grupo de querubins que o sustentam sobre uma densa nuvem, está Deus Pai. Um halo de luz resplandece atrás de sua cabeça, enquanto seu corpo tenta se acomodar diagonalmente sobre o anteparo. Veste roupa escura, e um manto vermelho envolve parte dos seus ombros, região pélvica e desce até o meio das pernas. Segura com a mão esquerda uma espécie de bastão, enquanto a

4 Anjo semelhante a este é encontrado no forro da Antiga Biblioteca dos Jesuítas, com pintura atribuída a Antonio Simões Ribeiro (Salvador, 1735-1755). Detalhes, ver: Vicente (2011, 2012). 
mão direita posiciona-se côncava, voltada para baixo e com dois dedos esticados, em direção às demais figuras da cenografia. Sua posição consolida a hierarquia proposta pela temática e pela Trindade; ele está no topo de toda a cena, observando, cuidando, "imposicionando" sua mão; se fazendo presente figurativamente. ${ }^{5}$

Figurar Deus nas obras de arte religiosa foi uma necessidade cristã. Por outro lado, há a dicotomia em tornar visível alguém que nunca foi visto. Para humanizá-lo, foi escolhida a figura de um velho, representação de sabedoria. Esse corpo nada mais é do que a figuração máxima das manifestações de um ser supremo e único. "Deus nunca foi visto por alguém. O Filho unigênito, que está no seio do Pai, esse o revelou”. (BIBLIA, 2005, Jo, 1: 18)

Seguindo o posicionamento das imagens, conforme a hierarquia apresentada pelo pintor no quadro central da obra, a leitura iconográfica será feita de baixo para cima.

Conforme a proposta de José Joaquim da Rocha, a base da grande cena está nas quatro figuras femininas, que representam os quatro continentes que dividiam o mundo no período do Brasil Colonial. A mensagem aqui inserida pode ser interpretada sob dois aspectos:

1. Simbolizando os homens e sua relação com Nossa Senhora, recorrendo a Ela, através de gestos ou ofertas; representação da humanidade rogando à Virgem;

2. Revelando a expansão do Cristianismo, onde todos os povos se curvam diante da grandeza de Maria.

Do lado esquerdo, América e Ásia, do lado direito, Europa e África. América tem o olhar direcionado à Virgem e as mãos postas em oração, como que agradecendo; Ásia olha para baixo e curva o corpo em constrição; Europa olha e aponta para a Imaculada e lhe oferece um objeto; e África olha para o alto, abre um dos braços enquanto a outra mão repousa no peito e lhe suplica. A humanidade se prosta humildemente aos pés da Virgem Santa, pedindo ou agradecendo; toda a cristandade reconhece a doutrina da Conceição Imaculada de Maria.

A alegoria aos quatro continentes em forma humana é antiga. Possuindo efeito simbólico e imagético, foram copiadas e ressignificadas em um número considerável de obras de linguagens diferentes, desde os brasões e os arcos triunfais joaninos até as pinturas, principalmente aquelas que estavam ligadas aos jesuítas e aos franciscanos, pois representavam a disseminação do catolicismo no mundo.

5 O ato de imposicionar as mãos, além de sabedoria, coloca aquele que a imposiciona como alguém poderoso. Lembra-se aqui a passagem bíblica sobre a morte de Moisés, em que Deus dá a ele esta condição: “[...] Ora, Josué, filho de Num, estava cheio do Espírito de sabedoria, porque Moisés tinha imposto as suas mãos sobre ele [...], pois ninguém jamais mostrou tamanho poder como Moisés nem executou os feitos temíveis que Moisés realizou aos olhos de todo o Israel”. (BIBLIA, 2005, Dt, 34: 9, 12) 
Algumas referências iconográficas podem ter sido significativas para a inserção dessas alegorias por José Joaquim da Rocha nesta pintura: a interpretação figurada e individual dos quatro continentes presentes nos azulejos do claustro do Convento de São Francisco de Salvador (Bahia); ${ }^{6}$ uma gravura de Pompeu Batoni, ${ }^{7}$ de temática relacionada ao Coração de Jesus (1790/1799); e gravuras representando a heráldica, de grande circulação no período colonial. Dessas três menções, a gravura de Batoni (Figura 2) revela a mesma composição organizacional e espacial do conjunto pictórico presente na nave da Conceição da Praia, onde a figuração dessas alegorias, situada na parte inferior, possui a mesma riqueza que Rocha pinta em sua obra. Em todos os adereços, elementos simbólicos e/ ou os animais que as acompanham são os indicadores para determinar os países que estão representando, tal como aparece na pintura.

Nossa Senhora está sobre a humanidade e abaixo do Cordeiro Santo. $\mathrm{Na}$ interpretação cristã, ela é a união entre o céu e a terra. Está entre os dois mundos e sobre o amor e a proteção maior da Trindade Santa; é o laço. Percorre o firmamento e reina na terra. Segura, com a mão esquerda, um ramalhete de (três) flores de açucena (sua pureza e a Trindade), enquanto sua mão direita está côncava e voltada para baixo. Esse ato posicionado pela mão destra remete à atitude de acolher, como em concordância aos pedidos que lhes foram feitos pela humanidade, devolvendo-lhes a cura de seus males. O toque não é real, mas é a transmissão dele, através do gesto e da graça, que é alcançada pelos homens. Seu semblante convida para contemplação, misericordiosidade e comunicação. Seus olhos seguem o expectador, mesmo que não estejam direcionados a eles.

Habitei nos lugares mais altos: meu trono está numa coluna de nuvens Sozinha percorri a abóbada celeste, e penetrei nas profundezas dos abismos. Andei sobre as ondas do mar,e percorri toda a terra. Imperei sobre todos os povos e sobre todas as nações. [...] Tive sob os meus pés, com meu poder, os corações de todos os homens, grandes e pequenos. Entre todas as coisas procurei um lugar de repouso, e habitarei na moradia do Senhor. [...] Então, a voz do Criador do universo deu-me suas ordens, e aquele que me criou repousou sob minha tenda. (BÍBLIA, 2005, Ecl, 24: 6-12)

6 Apesar das alegorias presentes nesse claustro se apresentarem individualmente, elas não são menos ricas em detalhes e símbolos decorativos. Ao conjunto total de azulejos, é registrada a datação entre 1749 e 1752, sendo em parte atribuída a mão de Bartolomeu de Jesus.

7 A referida gravura é dedicada à invocação do Coração de Jesus presente na Basílica da Estrela. A data de referência ao período em que esta foi concluída é a do início da regência oficial de D. João VI. É um trabalho executado por três pessoas: Pompeu Botoni inventou, Marcus Caricchia desenhou e Hieronymus Carattoni gravou/esculpiu. A técnica final utilizada foi o buril e a água forte. Foi feita em Roma, em preto e branco, e mede $53 \times 29 \mathrm{~cm}$. (Biblioteca Nacional do Porto, Coração De Jesus, Sessão manuscritos) 


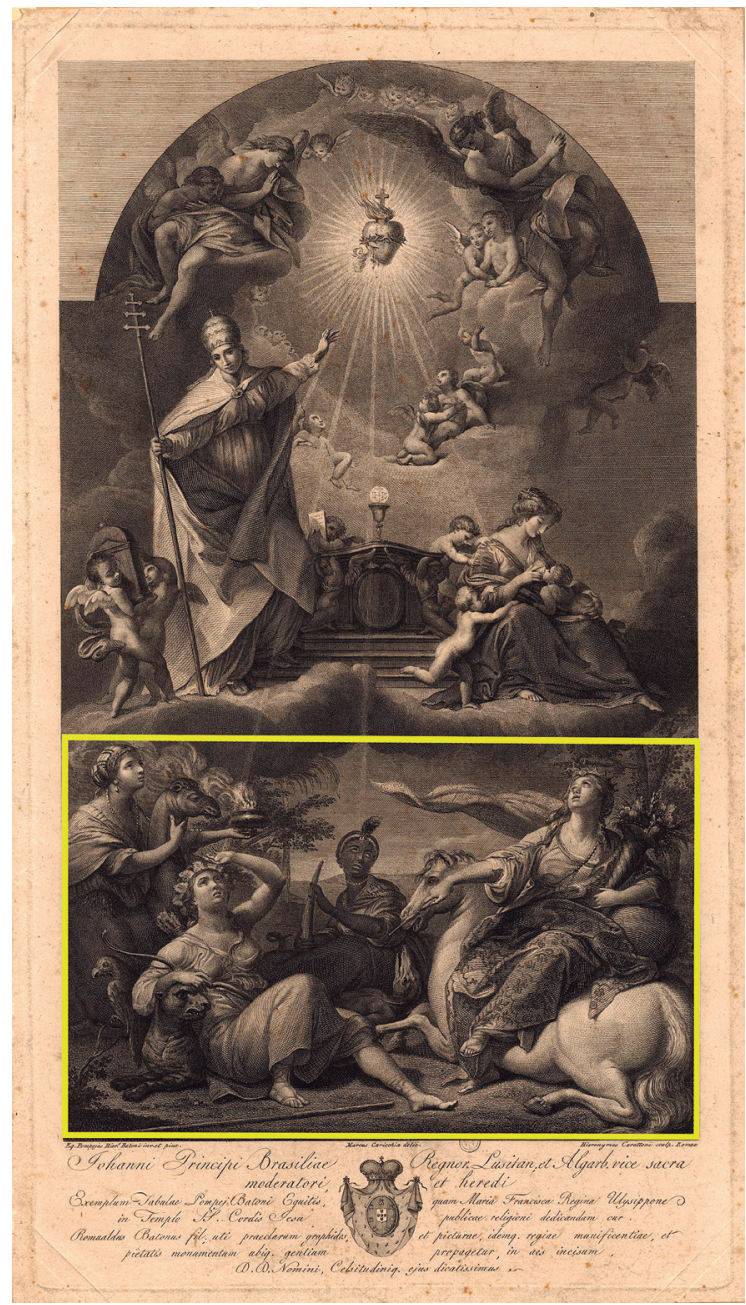

Figura 2 - Os quatro continentes ${ }^{8}$ de Pompeu Girolamo-Batoni (det.), c. 1790, "estudo o 2006-2011"

Fonte: Biblioteca Nacional de Portugal.

Sobre o resplendor de 12 estrelas que coroam Nossa Senhora, está o Cordeiro deitado sobre o Livro das Revelações. Livro do Primeiro e do Segundo Testamento; da Primeira e Segunda Aliança, cujo sentido simultaneamente é oculto e revelado. O Livro da Vida; do que somos. O segredo da verdade sobre o mundo, sobre os homens, seus mistérios; sobre tudo o que se fez e o que se está por fazer; o segredo da eternidade. Seu verdadeiro sentido, o sentido do ser, ainda é velado, selado, por isso, está fechado.

8 Detalhe da obra Coração de Jesus. 
A revelação está escrita e selada no Livro: o Livro dos 7 Selos, que, ao ser aberto, pronunciará o grande segredo. Um segredo protegido pelo Cordeiro Santo, seu guardião, que faz dele seu trono. Um dia, ele romperá o lacre e os sete mistérios cristãos serão decifrados. Ele é o único capaz de abri-lo, pois sua inocência, apesar de ferida pelo ódio e injustiça humana, the tira de qualquer julgamento e se faz humilde diante da sua missão. Até esse segredo ser pronunciado, os fiéis se curvam aos pés daqueles que podem chegar aos ouvidos de Deus levando seu clamor. Em se tratando da pintura, esse chamado se faz através da Virgem, que intercede sobre os dois mundos.

[...] É por isso que estão diante do trono de Deus, servindo-o dia e noite em seu templo. Aquele que está sentado no trono estenderá sua tenda sobre eles: nunca mais terão fome, nem sede, o sol nunca mais os afligirá, nem qualquer calor ardente: pois o Cordeiro que está no meio do trono os apascenterá, conduzindo-os até as fontes de água da vida. E Deus enxugará toda lágrima de seus olhos. (BÍBLIA, 2005, Jo, 7: 9-17)

[...] Quem é digno de abrir o Livro e de desatar os seus selos? E ninguém no céu, nem na terra, nem debaixo da terra, podia abrir o Livro, nem olhar para ele. E eu chorava muito, porque ninguém fora achado digno de abrir o livro, nem de o ler, nem de olhar para ele. (BÍBLIA, 2005, Jo, 5: 2-4)

Coroada pelas 12 estrelas, ela é a própria mulher do Apocalipse. "E viu-se um grande sinal no céu: uma mulher vestida do sol, tendo a lua debaixo dos seus pés, e uma coroa de doze estrelas sobre a sua cabeça". (BÍBLIA, 2005, Ap, 12: 1)

Do lado esquerdo do Cordeiro Santo, está São João Evangelista. O Apóstolo João, o mais jovem de todos e aquele que teria feito voto de virgindade, por isso, também apelidado de "o discípulo virgem". Foi o bem-amado de Jesus, um dos discípulos escolhidos para contemplar e experienciar sua vida; se autointitula "o discípulo que Jesus amou". Representa a contemplação ou inteligência sensorial, cuja capacidade está em discernir aquilo que é e do que lhe está à frente. Ao morrer, ocupou seu lugar de filho ao lado de Maria, com quem peregrinou em oração e palavras o que o verdadeiro filho pregou. Foi testemunho da vida de Jesus Cristo.

João Evangelista é tratado no último Livro bíblico como vidente, pois foi responsável pela revelação do final dos tempos. Ele revela o triunfo do Cordeiro de Deus sobre as batalhas terrenas, sua última vinda à Terra e a glória que será consumida pelos que forem eleitos. 
O cálice que segura nas mãos pode representar a Eucaristia, o momento em que Jesus ensina aos seus Apóstolos a partilhar e entender a doação da carne em prol da humanidade, assim como um atributo referente à sua iconografia: o cálice do veneno. ${ }^{9}$

Do lado direito, está a figuração de São João Batista, último Profeta do Antigo Testamento que pregou a vinda de Cristo. João Batista foi filho do milagre; nascido da velhice e esterilidade de seus pais (Isabel e Zacarias), sendo primo de Jesus. Sua vida e sua palavra o fizeram precursor de Jesus Cristo, cuja missão foi preparar o caminho e os homens para a chegada do Messias, proclamar o Reino que este semearia e batizá-lo dos pecados que não lhe pertenciam. Na iconografia medieval, na hierarquia da santidade, é o santo representado imediatamente abaixo de Maria. Os atributos que carrega consigo - cajado em forma de cruz, veste simples e em modelo medievo de pastor do deserto, descalço e viril - representam e identificam a sua própria missão na terra, assim como prenunciam a Daquele a quem prepara o caminho. "Houve um homem enviado por Deus; seu nome era João; este veio como testemunha, para dar testemunha da luz, a fim de que todos cressem por meio dele. Ele não era a luz, mas veio pra dar testemunho da luz". (BÍBLIA, 2005, Jo, 1: 6-9)

A vida de João Batista o preparou para desaparecer para que Jesus aparecesse, mas como seu discípulo seria o maior: "Digo-vos que, dentre os nascidos de mulher, não há um maior de que João, mas o menor no Reino de Deus é maior do que ele". (BÍBLIA, 2005, Jo, 7: 28)

Dentre as mensagens ocultas, colocadas na pintura por José Joaquim da Rocha, está a reafirmação da importante influência religiosa que teria a presença de João Batista na vida de Jesus e de Maria. Esse fato é apresentado através da cena que narra quando ainda estava no ventre materno, e Maria, prima de sua mãe, a visita. Essa passagem, nomeada por "Visitação", é confirmada pelo próprio ao apontar, com os dois dedos da mão esquerda, para a cartela ${ }^{10}$ que figura a cena, situada à sua lateral esquerda, enquanto se coloca de joelhos em diagonal ao Cordeiro Santo.

9 Nos ciclos dos apóstolos, João tem como emblema uma taça envenenadada qual escapa o veneno exorcizado por um sinal da cruz em forma de dragãozinho de uma ou várias cabeças. O atributo da taça envenenada é tardia (século XIII) e infrequente na pintura italiana, que o substituiu por um livro. No século XVII já não se compreendia o significado do dragãozinho alado, símbolo do poder do veneno, saindo da taça. De acordo com a tradição recolhida pelo Pseudo-Isidoro de Sevilha, havia-se intentado envenenar São João pelo cálice eucarístico, a taça envenenada. Por isso, com frequência, tem a forma de um cálice, onde, em lugar do dragão, em cima recipiente, representa-se uma hóstia. (RÉAU, 2001, p. 186-199; RIBADENEYRA, 1790, p. 638-650)

10 Há, ainda, na pintura, duas cartelas situadas na moldura quadraturística, que reafirmam o caráter imaculado de Maria: uma representa a visita do anjo lhe proclamando como a escolhida para dar a luz àquele que seria o filho do Verbo (Anunciação); a outra representa Deus se manifestando em seu ventre quando ela vai anunciar a chegada do sobrinho (Visitação). 
E aconteceu que, ao ouvir Isabel a saudação de Maria, a criancinha saltou do seu ventre; e Isabel foi cheia do Espírito Santo. E exclamou com grande voz, e disse: Bendita és tu entre as mulheres, e bendito o fruto do teu ventre. Pois eis que, ao chegar aos meus ouvidos a voz da tua saudação, a criancinha saltou de alegria no meu ventre. (BÍBLIA, 2005, Lc, 1: 41-42-44)

A representação dos dois Joãos na cena não é por acaso; ao ladear o Cordeiro, reafirmam a missão que cada um teve: prever e anunciar a salvação por meio do enviado de Deus.

Vós mesmos sois testemunhas de que eu disse: Não sou eu o Cristo, mas sou enviado adiante dele. Quem em a esposa é o esposo; mas o amigo do esposo, que está presente e ouve, é tomado de alegria à voz do esposo. Essa é a minha alegria e ela é completa! É necessário que ele cresça e eu diminua. (BÍBLIA, 2005, Jo, 3: 27-30)

João batizava no rio Jordão, viu Jesus se aproximar e disse: Eis o Cordeiro de Deus, que tira o pecado do mundo. Este é aquele do qual eu disse: Após mim vem um homem que é antes de mim, porque foi primeiro do que eu. E eu não o conhecia; mas para que ele fosse manifestado a Israel, vim eu, por isso, batizando com água. (BÍBLIA, 2005, Jo, 3: 29-31)

Dentro dos textos litúrgicos, o Apocalipse ainda registra a presença de figuras misteriosas chamadas "Duas Testemunhas", reafirmando o que aqui se narra: “[...] E darei poder às minhas duas testemunhas, e profetizarão por mil duzentos e sessenta dias, vestidas de saco [...]". ${ }^{11}$ (BÍBLIA, 2005, Ap, 11:3)

O Espírito Santo está acima do Cordeiro e é representado pela pomba. Do seu entorno, saem feixes luminosos. A nuvem que a envolve se une à própria nuvem em que está Deus Pai. Nuvem e luz são símbolos inseparáveis nas manifestações do Espírito Santo, tratados nos escritos sobre as manifestações de Deus desde o Antigo Testamento. A nuvem, às vezes escura, outras vezes luminosa, representa o Deus vivo e salvador, que vela a transcendência da sua glória. É a realização por Cristo através do próprio Espírito Santo, sendo Ele quem que desce sobre a Virgem Maria e a cobre "com a sua sombra", para que conceba e dê à luz (Jesus). (MORGADO OFM, 2013) A nuvem em que se insere é a que sefez ouvir uma voz que dizia: "Este é o meu Filho, o meu Elei-

11 Embora algumas opiniões tratem dessas duas figuras como sendo Moisés e Elias, na pintura aqui estudada propõe-se uma nova interpretação diante das pistas encontradas, mesmo porque não é assertiva a identidade de tais testemunhas, permanecendo, assim, uma incógnita. 
to, escutai-O!" (BÍBLIA, 2005, Lc, 9: 35), sendo a mesma que “esconde Jesus aos olhos" dos discípulos no dia da Ascensão e que O revelará como Filho do Homem na sua glória, no dia da sua vinda. ${ }^{12}$

A pomba indica que Deus se faz presente no ressoar da Sua voz sobre os homens. Ao findar o dilúvio (simbolismo com o Batismo), Noé solta uma pomba que retorna com um ramo de oliveira preso ao bico - a terra que encontra é habitável. É também em forma de uma pomba que o Espírito Santo está sobre a cabeça de Jesus no momento do seu Batismo. A sua iconografia é comum em cenas religiosas em que Ele está presente, prestigiando atos significativos, como o "Batismo de Cristo por João Batista", "Pentecostes", "Coroação de Nossa Senhora", "Anunciação", "Visitação" e demais obras significativas relacionadas à ascensão de Santos.

Acima do Espírito Santo, e concluindo as figurações, está Deus humanizado. Hierarquicamente, está acima de todos, sobre o comando de tudo. Observa e participa, ao mesmo tempo em que se propõe como mensageiro (pomba) das suas leis. Ele é parte da Trindade (Pai), criador do mundo, o próprio Filho enviado para salvação e, quando não humano, são os feixes de luz refletidos ou a figuração da pomba. Apresenta, pela mão direita que abençoa, toda a cena, e ainda, com dois dedos esticados, simboliza que as duas naturezas cristãs estão unidas sem confusão e sem separação; os outros três dedos significam a Uni-Trindade. Esta mão que consagra está direcionada à terra, à humanidade. Os dedos estendidos são um convite a unir-se ao divino, enquanto os dobrados são um convite à entrada para manifestar no conhecimento da Palavra proposta pela Trindade. "Poderíamos dizer que a mão é dotada de visão, ao passo que o olho é dotado de certo tipo de tato. Visão e tato levam ao Conhecimento que liberta". (SOUZENELLE, 1991, p. 336) A mão de Deus sempre abençoa. Ela é a referência direta da mão do Pai.

\section{Estudos da composição triangular sob o olhar iconográfico}

Nota-se, imediatamente, o domínio da técnica e uso das leis para traçar a perspectiva por José Joaquim da Rocha, utilizando, inclusive, elementos e construções matemáticas e de falsa arquitetura na moldura quadraturística que envolve a cenografia central. Curiosamente, e isso é parte de uma estética cultural presente na Bahia, a grande cena não está reposicionada como as quadraturas ilusionistas italianas, nas quais os personagens estão disotto in sú, se abrindo para o céu. A perspectiva tratada pelo pintor na composição é por planos, e, por se tratar de uma iconografia sacra, ele usa a hierarquia para estabelecer o posicionamento de cada figura, ao mesmo tempo em que inscreve, ocultamente, a mensagem cristã.

12 Ver em: http://www.vatican.va/archive/cathechism. 
Segundo Casimiro (2005), há um esquema geométrico de composição que esteve na gênese estrutural das pinturas com a finalidade de reforçar a mensagem subjacente proposta ao tema (mensagem oculta) que veio comprovar o conhecimento das leis da perspectiva por parte dos pintores. Tal esquema foi utilizado como forma de proporcionar os diversos elementos pictóricos e reforçar a respectiva mensagem iconográfica.

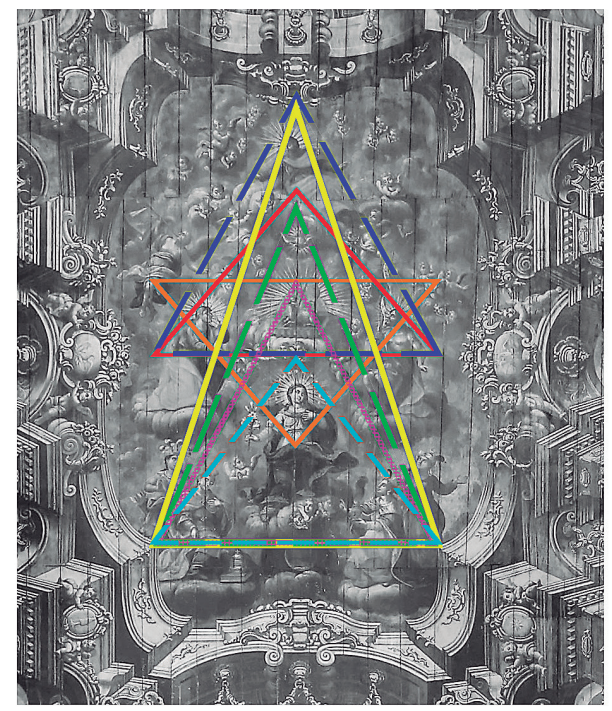

\begin{tabular}{|l|l|}
\hline--- & $1^{\text {a }}$ Trilogia: Os quatro Continentes e a Virgem \\
\hline & $2^{\text {a }}$ Trilogia: Os quatro Continentes, a Virgem e o Cordeiro \\
\hline--- & $3^{\text {a }}$ Trilogia: Os quatro Continentes, a Virgem, o Cordeiro e o Espírito Santo \\
\hline & $4^{\text {a } T r i l o g i a: ~ O s ~ q u a t r o ~ C o n t i n e n t e s, ~ a ~ V i r g e m, ~ o ~ E s p i ́ r i t o ~ S a n t o, ~ o ~ F i l h o ~ e ~ o ~ P a i ~}$ \\
\hline-- & $5^{\text {a } T r i l o g i a: ~ J o a ̃ o ~ E v a n g e l i s t a, ~ S a ̃ o ~ J o a ̃ o ~ B a t i s t a ~ e ~ o ~ E s p i ́ r i t o ~ S a n t o ~}$ \\
\hline & $6^{\text {a } T r i l o g i a: ~ O ~ P r e c u r s o r ~(J o a ̃ o ~ B a t i s t a), o ~ A p o ́ s t o l o ~(J o a ̃ o ~ E v a n g e l i s t a) ~ e ~ D e u s ~}$ \\
\hline & $7^{\text {a } T r i l o g i a: ~ A ~ m a ̃ e ~ d e ~ J e s u s, ~ o ~ P r i m o ~ e ~ o ~ A p o ́ s t o l o ~}$ \\
\hline
\end{tabular}

Figura 3 - Leitura gráfica das representações esquemáticas triangulares presente no quadro recolocado do forro da nave da Igreja de Nossa Senhora da Conceição da Praia ${ }^{13}$

Fonte: Vicente (2011).

Diante da complexidade que envolve o estudo geométrico para a pintura na sua totalidade, atentar-se-á aqui apenas ao esquema de composição triangular utilizado pelo pintor que, com maestria técnica, exibe amplo domínio na representação das figuras para serem vistas de baixo, percebendo a importância,

13 Nas Figuras 3, 4 e 5, houve estudo e intervenção da autora para leitura iconográfica. 
nobreza e imponência de cada uma. O uso deste esquema, comum nas obras de sua autoria, fez com que conciliasse trilogias que envolvem os personagens em relações entre si, ou seja, o posicionamento de cada um não está ali por acaso e há uma mensagem entre eles. $\mathrm{O}$ triângulo remete à multiplicidade das tríades relativas ao nascimento, à vida e à morte; ao céu, à terra/homem e à alma/espírito; ao pai, à mãe e ao filho. Especificamente nesta obra, a princípio, o triângulo tem uma relação cristã e está associado à Santíssima Trindade e à Imaculada. Não deve ser esquecido que a representação triangular tem características renascentistas, revelando, também pelo pintor, adoção de conhecimentos da cientificidade tratadístico-geométrica na estruturação gráfica.

Sete triângulos foram identificados na composição, sendo seis ascendentes e um descendente. Dos seis, três possuem base nas Alegorias dos quatro continentes e três nas personificações dos Joãos. Por se tratar de uma leitura sacra, associada aos três representantes máximos do catolicismo, será identificada como "Trilogia" (Figura 3).

A primeira Trilogia é composta pelas alegorias dos quatro continentes e pela Virgem, em que Maria, sendo a mãe de Deus, é também a mãe dos homens. "Glorificada já em corpo e alma, [...] brilha como sinal de esperança segura e de consolação, para o Povo de Deus ainda peregrinante, até que chegue o dia do Senhor". ${ }^{14}$

O universo visível e invisível é testemunho do amor de Maria pelo seu filho e pelos homens, por quem se faz medianeira e intercessora. É infinita porque é a extensão de Deus; a extensão de um amor incondicional. Sua morte não a levou por completo para o mundo celestial para ocupar seu lugar ao lado do Pai e do Filho, mas a manteve presente no presente, pois nela os homens confiam seus pedidos para chegar a Jesus e a Deus. Sua glorificação não é marcada por um momento, mas é movimentada ciclicamente pela necessidade e pelo clamor dos indivíduos em falar com o Pai.

O Senhor me possuiu no princípio de seus caminhos, desde então, e antes de suas obras.

Desde a eternidade fui ungida, desde o princípio, antes do começo da terra.

Quando ainda não havia abismos, fui gerada, quando ainda não havia fontes carregadas de águas.

Antes que os montes se houvessem assentados, antes dos outeiros, eu fui gerada;

14 Ver: Lumen Gentiun, A bem-aventurada Virgem Maria mãe de Deus no mistério de Cristo e da Igreja. Cap. VIII, v. 68 
Ainda ele não tinha feito a terra, nem os campos, nem o princípio do pó do mundo.

Quando ele preparava os céus, aí estava eu, quando traçava a horizonte sobre a face do abismo;

Quando firmava as nuvens acima, quando fortificava as fontes do abismo,

Quando fixava ao mar o seu termo, para que as águas não traspassassem o seu mando, quando compunha os fundamentos da terra.

Então eu estava com ele, e era seu arquiteto; era cada dia as suas delícias, alegrando-me perante ele em todo o tempo;

Regozijando-me no seu mundo habitável e enchendo-me de prazer com os filhos dos homens.

Agora, pois, filhos, ouve-me, porque bem-aventurados serão os que guardarem os meus caminhos!

Ouvi a instrução, e sede sábios, não a rejeiteis.

Bem-aventurado o homem que me dá ouvidos, velando às minhas portas cada dia, esperando às ombreiras da minha entrada.

Porque o que me achar, achará a vida, e alcançará o favor do Senhor. [...]. (BÍBLIA, 2005, Pv, 8: 22-35)

A segunda Trilogia, formada pela personificação dos quatro continentes, a Virgem e o Cordeiro, está associada ao Cristo humano e sua vida enquanto "Bom Pastor” de pessoas. Maria não é Deus, mas é a representação humana que permitiu Aquele que foi destinado a se tornar humano. O Cordeiro é a imagem da entrega sem sacrifício, da inocência, mesmo que ferida, da luz que emanou do Pai celestial. Um cordeiro que foi enviado pelo seu pai para salvar a humanidade; o próprio Jesus, filho de Deus. Pôs-se a prova, pois dela necessitaria para a salvação dos homens. Enquanto isso, Maria está entre o mundo e o filho, se faz presente para que Ele nasça. Ela é a medianeira de todas as graças e, por ela, passam os pedidos ao Cristo. Escolhida por Deus para participar do mistério da Redenção, é o elo direto entre os fiéis e Cristo.

A terceira Trilogia é formada pela personificação dos quatro continentes, a Virgem, o Cordeiro e o Espírito Santo, que é o amor de Deus e revela-O pleno e único. Um Espírito que recai sobre a humanidade, proporcionando-lhes a misericórdia e a caridade, assim como a imagem e semelhança de Deus. Para conhecer o verdadeiro Pai, é preciso tornar-se o Filho amado e, para tal, o agir do Espírito 
Santo é necessário. Essa ação (Pentecostes) é uma transformação do mundo antigo para o novo através da presença do Espírito Santo.

O corpo do cristão é templo do Espírito Santo. ${ }^{15}$

(I Co, 6: 19-20)

Nós não recebemos o espírito do mundo, mas o Espírito que vem de Deus, a fim de conhecermos as coisas que, por Deus, nos foram prodigalizadas. (I Co, 2: 12-14)

Mas aquele Consolador, o Espírito Santo, que o Pai enviará em meu nome, esse vos ensinará todas as coisas, e vos fará lembrar de tudo quanto vos tenho dito. (Jo, 14: 26)

Deus Pai amou Maria, escolhendo-a como Mãe de seu Filho. O Espírito Santo desceu sobre ela. (Lc, 1: 35)

A quarta Trilogia tem, na sua formação, a personificação dos quatro continentes, a Virgem, o Espírito Santo, o Filho e o Pai. Pai, Filho e Espírito Santo representam o ícone da Trilogia Santa; uma trilogia indivisível e única - Deus Pai, Deus Filho e Deus Espírito Santo - que reina visível para quem nela crê e invisível para quem ela protege. "Porque três são os que testificaram no céu: o Pai, a Palavra e o Espírito Santo; e estes três são um”. (BÍBLIA, 2005, Jo, 5: 8)

A ligação direta entre esta Trilogia e a humanidade é a Virgem, aquela que está entre os dois mundos, sendo intermediadora. Nossa Senhora intercede pela humanidade junto ao Pai, através do seu Filho e do Espírito Santo. "E o Verbo se fez carne, e habitou entre nós, e vimos a sua glória, como a glória do unigênito do Pai, cheio de graça e de verdade". (BÍBLIA, 2005, Jo, 1:14)

A quinta Trilogia está representada pelas figuras do João Evangelista, de São João Batista e do Espírito de Deus (pomba). O Cordeiro que figura no centro da Trilogia é o próprio Jesus Cristo, aquele que foi enviado pelo Pai e que deu sua vida pelos homens. A presença dos dois Joãos intercedidos pelo Espírito Santo traduz que Deus se fez luz sobre eles para que pudessem levar a mensagem da vinda do Messias. Sem conhecê-LO, promulgaram sua chegada e a salvação para aqueles que o seguissem. "Eu vi o Espírito descer do céu, como pomba, e repousar sobre ele". (BÍBLIA, 2005, Jo, 1: 32)

A sexta Trilogia consolida a quinta e, nela, figuram o Precursor (São João Batista), o Apóstolo (João Evangelista) e Deus Pai. Por intercessão divina, um homem prediz a vinda do Salvador, o outro será aquele que o acompanhará e viverá a existência do Filho de Deus junto aos homens. É sob o Espírito de Deus

15 Esse trecho e os subsequentes foram retirados da Bíblia (2005). Optou-se por mantê-los dessa forma para que não haja uma repetição. 
que esses dois homens testemunham e anunciam que haveria uma Aliança entre o céu e a humanidade e que, através do Verbo, se conheceria o poder da salvação.

E João deu testemunho dizendo: 'Vi o Espírito descer, como uma pomba, vindo do céu, e permanecer sobre ele. Eu não o conhecia, mas aquele que me enviou para batizar com água disse-me: 'Aquele sobre quem vires o Espírito descer e permanecer é o que batiza com o Espírito Santo'. E eu vi e dou testemunho que ele é o Eleito de Deus'. (BÍBLIA, 2005, Jo, 1: 26-34-36)

A sétima Trilogia é formada pelas figuras de João Batista, do Apóstolo João e de Maria, ou seja, a mãe de Jesus, o primo e o Apóstolo. Do grupo de triângulos ocultamente posicionados, é o único invertido, tendo seu vértice apontado para o ventre da Virgem, local onde acolheu e gerou o Messias. Unida à quinta trilogia, ela fecha simbolicamente a estrutura da Eterna Aliança. Alguns povos (China, Suméria, entre outras) associam o triângulo invertido à fertilidade feminina, à mulher e à receptividade, sendo o útero o órgão receptor.

[...] Bendita és tu entre as mulheres, e bendito é o fruto do teu ventre! (Lc, 1: 42)

Ora Jesus, vendo ali sua mãe e, que o discípulo a quem ele amava estava presente, disse a sua mãe: 'Mulher, eis o teu filho'. Depois disse ao discípulo: 'Eis aí tua mãe! [...]'. (Jo, 19: 26-27)

A significação do sétimo triângulo possivelmente é a decodificação de um dos segredos da narrativa, intencionalmente criada, mas projetada oculta pelo artista. Resguardada nos textos sagrados, parece estar cuidadosamente velada, sendo capaz de entendê-la quem se debruça ao estudo da obra, a partir da interpretação das escrituras cristãs e de Evangelhos não reconhecidos, ditos Apócrifos.

Deve-se lembrar que a relação de Maria com João Batista era de parentela direta. A ele foi dada a oportunidade de acompanhar Jesus desde criança. O elo entre eles foi forte, e este João foi o escolhido, pois estava destinado a anunciar a vinda do Messias.

O João Evangelista, o Apóstolo, estava entre os preteridos e foi indicado para semear a história daquele que morreu pelos homens, assim como anunciar o seu retorno. Foi ele quem sofreu aos pés do calvário junto a Maria e de lá só saiu quando Jesus estava deposto. Um homem que sofreu com, por e depois; um filho que ganhou o lugar do outro, ao lado da Santíssima Mãe.

Diante disso, o prenúncio e a narrativa ficam subentendidos quando se observa que, em vértice oposto a esses dois homens, está o ventre de Maria, o local onde esteve Aquele por quem eles promulgaram, louvaram e semearam a 
palavra. Do ventre de uma mulher, foi trazido para a vida um Espírito de Deus, em forma humana.

$\mathrm{Na}$ medida em que as estruturas triangulares se completam, vê-se uma figura simbólica e importante, que toma força dentro da estrutura gráfica: uma estrela de seis pontas gerada a partir de dois triângulos em posições opostas. O vértice do triângulo descendente aponta para o útero de Maria, enquanto os vértices da sua base têm as figuras do Apóstolo e do primo de Jesus. Ou seja, a Trilogia composta pelo Apóstolo João, por São João Batista e pela Pomba está contrária a Trilogia formada pelo Apóstolo João, por São João Batista e pela Imaculada. Sobrepostas, formam a Estrela de Davi, ou o Selo de Salomão. Uma aliança representada pelos mundos celestial e terreno. João Batista e João Evangelista representando o terreno - semeadores e narradores; Jesus, o enviado, representando o celestial. A condição de Maria é aquela que possibilitou a reconciliação dos dois mundos, a configuração da aliança sagrada. "Dois triângulos se encaixam: o escudo de David. A aliança está concluída. Não mais duas alianças: a única aliança, na qual nem a primeira nem a última se anulam, mas uma na outra se completam". (PONNAU, 2006, p. 94)

Simbolicamente, essa estrutura é o ícone do povo israelita e está relacionado à proteção e à sabedoria divina. Com a estrela formada, está concluída a eterna e única aliança - "o registro do nascimento de Jesus Cristo, filho de David, filho de Abrãao”. (BÍBLIA, 2005, Mt, 1:1)

Bem-aventurado tu, ó Israel! Quem é como tu? Um povo salvo pelo SENHOR, o escudo do teu socorro, e a espada da tua majestade; por isso os teus inimigos te serão sujeitos, e tu pisarás sobre as suas alturas. (Dt, 33: 29).

Ele reserva a verdadeira sabedoria para os retos. Escudo é para os que caminham na sinceridade. $(\mathrm{Pv}, 2: 7)$

Toda a Palavra de Deus é pura; escudo é para os que confiam nele. (Pv, 30: 5)

A interpretação da "Estrela de Davi” possui vários significados e, na maioria deles, há uma relação direta com a abordagem cristã interpretada pela presença das Trilogias. Deve-se olhá-la enquanto símbolo, e não como uma redução esquemática gráfica. A presença da Estrela no contexto da obra não parece ter sido por acaso, visto que as relações criadas pelo pintor permitem que a leitura seja clara, quando se conhece e estuda sobre iconografia cristã.

$\mathrm{Na}$ formatação trabalhada por Rocha, a estrutura da Estrela possui identidade; são nomes, situações sagradas e combinações que reafirmam a presença do orago (Virgem) no ponto central da obra favorecendo a leitura das suas interpretações. 
De acordo com os estudos sobre essa reprodução, se os seis pontos representados pelos vértices estiverem combinados com o ponto central, esse sétimo ponto significa transformação. Observando cada Trilogia que a forma estrelar permite evocar (São João Evangelista, São João Batista e Deus Pai; São João Evangelista, São João Batista e a humanidade), o referencial central da grande transformação proposta pela cenografia é exatamente a Imaculada, intercedida pelo Cordeiro e pelo Espírito Santo.

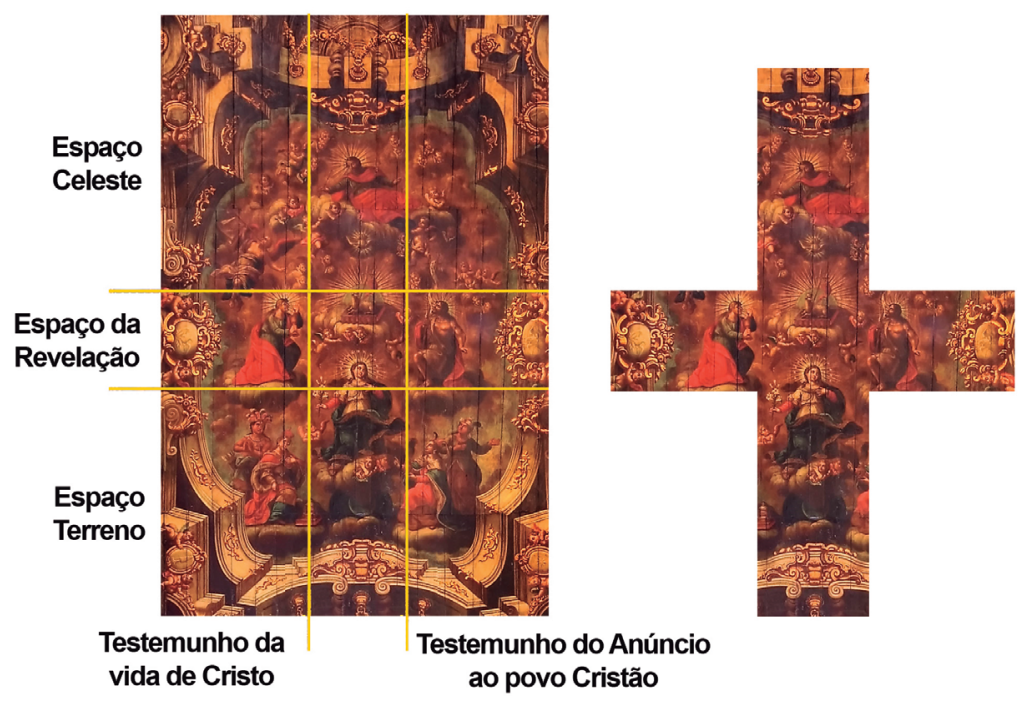

Figura 4 - Esquema vertical e horizontal da estrutura tripartida Esquema da estrutura compositiva da cruz oculta

Fonte: Vicente (2011).

Ainda é possível perceber ocultamente a presença do pentagrama. ${ }^{16}$ Fazendo uma relação entre ele e o Selo de Salomão, tem-se nele o aspecto humano e, no Selo, o aspecto divino. Dentre alguns estudiosos de visão platônica, Leonardo Da Vinci via perfeição matemática na forma humana e percebia que o corpo (humano) estava inserido na figura ideal do círculo e nas perfeitas proporções do quadrado. Com esse entendimento, interpretou os signos do homem, da ciência e do divino em um desenho conhecido como "Estudo de proporções", que foi

16 O pentagrama foi usado na Mesopotâmia como um símbolo do poder real, que se estendeu pelos quatro cantos do mundo. Entre os hebreus, o símbolo estava relacionado com a verdade e representava o Pentateuco. Dentro do Cristianismo, era usado como um amuleto contra o mal, e a própria Igreja utilizou-se dele para simbolizar as cinco chagas de Jesus. 
definido por Protágoras ${ }^{17}$ como "o homem é a medida de todas as coisas" e pelo Velho Testamento como "Sois Deuses". Da Vinci não desenhou os signos, pois, naquela época, seria considerado herege, mas deixou-os ocultos, sugeridos apenas a quem os conhecessem. A observação atenta à pintura da Conceição da Praia indica que Rocha aplica leis matemáticas e, possivelmente, algum conhecimento da linguagem secreta, dentro da sua concepção, na qual a presença dessa estrutura é, por assim dizer, determinada como elo central da Igreja e do mundo.

A pintura está dividida em uma composição tripartida, com três espaços verticais e três espaços horizontais (Figura 4). Essa divisão em espaços determinados e esquematicamente colocados faz com que cada personagem esteja situado em sua área, sem avançar a outra. Isso também estabelece uma leitura que pode ser seguida de acordo com a hierarquia cristã.

Esta estrutura também remete aos três degraus que compõem um altar, representando: o sacrifício (humanidade recorrendo à Virgem), a morte (Jesus morto na figura do Cordeiro) e a ressurreição (Espírito Santo/Deus); podendo também estar relacionada diretamente à Trindade.

A estrutura horizontal se divide em espaço celestial, espaço terreno e o espaço da revelação. A vertical, no anúncio ao povo cristão (lado direito), o testemunho da vida de Cristo (lado esquerdo) e o elo entre o céu e a terra; entre Deus e a humanidade (centro). No espaço celestial, há uma representação da vigília de Deus, da sua criação, de onde observa atento.

Assim diz o Senhor: o céu é o meu trono e a terra o escabelo dos meus pés [...] Porque a minha mão fez todas estas coisas, e assim todas elas foram feitas [...]. (BÍBLIA, 2005, Is, 66: 1-2)

[...] Bendita do SENHOR seja a sua terra, com o mais excelente dos céus, com o orvalho e com o abismo que jaz abaixo. E com os mais excelentes frutos do sol, e com as mais excelentes produções das luas. E com o mais excelente dos montes antigos, e com o mais excelente dos outeiros eternos. E com o mais excelente da terra, da plenitude, e com a benevolência daquele que habitava na sarça [...]. (BÍBLIA, 2005, Dt, 33: 13-16)

O espaço terreno, representando a morada da humanidade, está amplamente figurado com a presença da alegoria aos quatro continentes, ou seja, a abrangência do poder divino para todos os povos e raças.

17 Protágoras de Abdera (Abdera, 480 a.C./Sićlia, 410 a.C.). Sofista grego responsável por cunhar a frase "o homem é a medida de todas as coisas, das coisas que são, enquanto são, das coisas que não são, enquanto não são". (PROTÁGORAS, [20--?]) 
No espaço da revelação, tem-se a adoração ao Cordeiro Santo e ao Livro das Revelações, ou Livro dos 7 Selos.

O anúncio da vinda do Messias ao povo cristão é feito por João (Batista), o precursor. "Eu vi e sou testemunho que ele é o Eleito de Deus". (BÍBLIA, 2005, Jo, 1: 29-30) Ele está na mesma zona em que se encontram as figurações do povo terreno, neste lado representado pela África e Europa. "Eis o Cordeiro de Deus, que tira o pecado do mundo. Este é aquele do qual eu disse: Após mim, vem um homem que é antes de mim, porque foi primeiro do que eu". (BÍBLIA, 2005, Jo, 1: 34)

O testemunho da vida de Cristo é feito através de João, o Apóstolo, pois o fato de ter sido o escolhido é porque saberia falar sobre a vida e a obra Daquele com quem conviveu e aprendeu as leis cristãs. Quando fala aos homens sobre o Messias, ele prega que "no princípio era o Verbo, e o Verbo estava com Deus, e o Verbo era Deus. Nele estava a vida, e a vida era a luz dos homens”. (BÍBLIA, 2005, Jo, 1: 1-4)

Maria é posta como elo entre o reino celestial e o terreno. É ela quem fala diretamente ao Senhor através de seu Filho; intercede em favor dos homens e deles leva a mensagem ao Pai.

Dirijam todos os fiéis instantes súplicas à Mãe de Deus e mãe dos homens, para que Ela, que assistiu com suas orações aos começos [...], também agora, exaltada sobre todos os anjos e bem-aventurados, interceda, junto de seu Filho, na comunhão de todos os santos. [...]. ${ }^{18}$

Portanto, o mesmo Senhor vos dará um sinal. Eis que a virgem conceberá, e dará à luz um filho, e chamará o seu nome Emanuel. (BÍBLIA, 2005, Is, 7: 14)

Com a estrutura tripartida definida, tem-se ainda a concepção misteriosa da narrativa do pintor, oculta pelo símbolo que o Cristianismo imprime na vida de sofrimento do Messias em relação aos homens. Como se cunhadas na cruz estivessem as figuras que consolidam e auxiliam na constituição da Eterna Aliança: Deus, Maria, o Apóstolo e o Precursor. Ao centro dela, o Cordeiro Imolado, símbolo da nova Era e dessa Aliança, representando Aquele que foi entregue ao mundo para salvá-lo: "Porque Deus amou o mundo de tal maneira que deu o seu Filho unigênito, para que todo aquele que nele crê não pereça, mas tenha a vida eterna” (BÍBLIA, 2005, Jo, 3: 16).

Toda a cena parece se tratar do julgamento final; o momento em que precede a decisão, pois o Livro ainda está fechado (selado) e o Cordeiro Santo (Jesus Cristo)

18 Ver: Lumen Gentiun, A bem-aventurada Virgem Maria mãe de Deus no mistério de Cristo e da Igreja. capítulo VIII, v. 69. 
o guarda. Tem-se, neste instante, a representação do Agnus Dei: "Eis o Cordeiro de Deus, Aquele que tira o pecado do mundo" (BÍBLIA, 2005, Jo, 1: 29) (Figura 5).

[...] Um livro escrito por dentro e por fora selado com sete selos [...]. Digno és de tomar o livro e abrir os selos, porque fostes imolado e com teu sangue comprastes para Deus homens de toda tribo, língua, povo e nação. (BÍBLIA, 2005, Ap, 5: 1-9)

Bem-aventurados aqueles que lê, e os que ouvem as palavras desta profecia, e guardam as coisas que nela está escrita, porque o tempo está próximo!

Eis que [Ele] vem com as nuvens, e todo o olho o verá, até os mesmos que os traspassaram; e todas as tribos da terra se lamentarão sobre ele. Sim! Amém! (BÍBLIA, 2005, Ap, 1: 3-7)

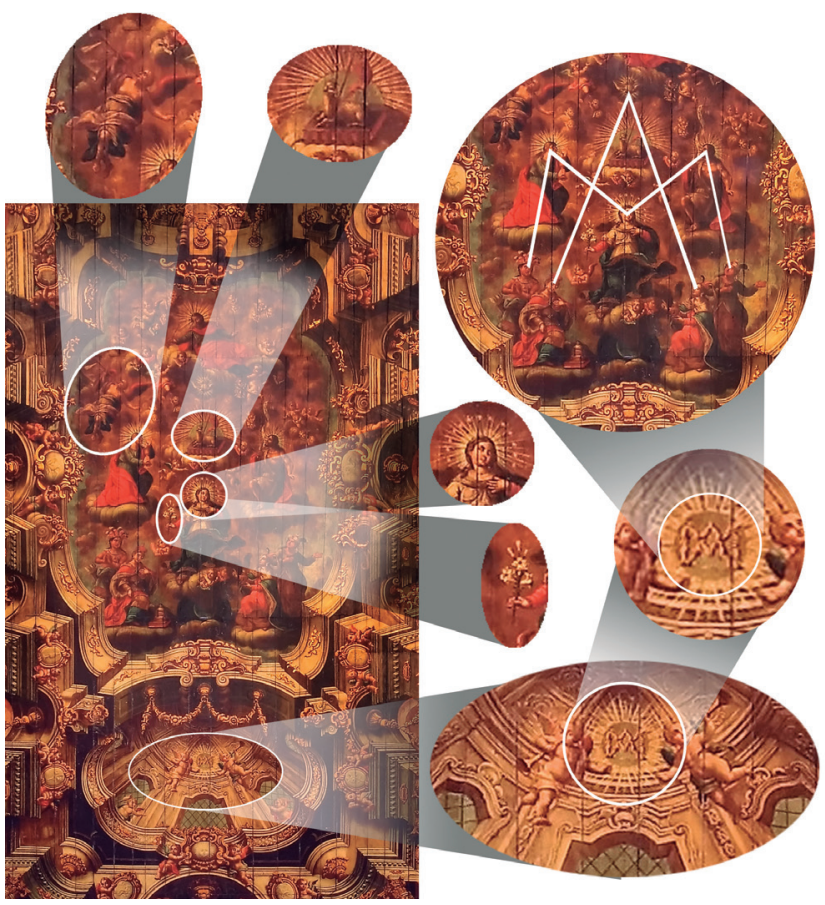

Figura 5 - Figuras e Símbolos iconográficos - (Agnus Dei - Cordeiro sobre o livro selado, Anjo Anunciador, Flores de Açucena, Maria Coroada de 12 Estrelas)

Fonte: Vicente (2011) 
Um anjo empunhando uma trombeta ${ }^{19}$ (Figura 5) anuncia a grande hora e aponta para o Cordeiro, onde está o Livro, que será aberto; é o sétimo anjo, ${ }^{20}$ o anjo do Apocalipse. "E vi um anjo forte, bradando com grande voz: 'Quem é digno de abrir o livro e lhe desatar os seus selos?" (BÍBLIA, 2005, Ap, 5: 2) E a resposta está na própria pintura: "[...] Não chores, eis aqui o Leão da tribo de Judá, a raiz de David, que venceu, para abrir o livro e desatar os seus sete selos.” (BÍBLIA, 2005, Ap, 5: 5) É o próprio Cordeiro: Jesus Cristo.

A cenografia central ainda apresenta a indicação da Trilogia Santa através do símbolo de pureza, inocência e virgindade, reafirmando a presença de Nossa Senhora na pintura. Esse símbolo é um ramo com três brotos e três flores de açucena que a Imaculada traz na mão direita (Figura 5). A representação da açucena também está relacionada à pureza esplendorosa e à entrega confiante à vontade de Deus. (MOHR, 1994, p. 222) É símbolo da Trindade ou da sua virgindade espiritual tripla (antes, durante e depois do parto).

Maria, coroada de estrelas, está ao centro da obra, ao centro da narrativa iconográfica (Figura 5). Medianeira entre o celeste e o terreno, é a mulher do anúncio:

Enriquecida, desde o primeiro instante da sua conceição, com os esplendores duma santidade singular, a Virgem de Nazaré é saudada pelo Anjo, da parte de Deus, como 'cheia de graça'; e responde ao mensageiro celeste: 'eis a escrava do Senhor, faça-se em mim segundo a tua palavra'. ${ }^{21}$

E viu-se um grande sinal no céu: uma mulher vestida do sol, tendo a lua debaixo dos seus pés, e uma coroa de doze estrelas sobre a sua cabeça. (BÍBLIA, 2005, Ap, 12: 1)

E o muro da cidade tinha doze fundamentos e, neles, os nomes dos doze apóstolos do Cordeiro. (BÍBLIA, 2005, Ap, 21: 14)

Ainda é possível cogitar que José Joaquim da Rocha tenha se utilizado de alguns artifícios simbólicos, deixando-os ocultos para assinar a identidade da

19 Figura alada semelhante está presente nas pinturas do teto do Oratório dos Vanchetoni (Florença), executada por Pietro Liberi, em 1641, na Sala de Alexandre - Museu DegliArgenti, do Palácio Pitti (Florença) -, e no subcoro da igreja do Hospital de Jesus (Portugal). Em Salvador, está no teto da antiga Biblioteca dos Jesuítas, como já citado anteriormente. Esses anjos não estão dispostos em mesma projeção, estando alguns em voo zenital, outros em frontalidade. O importante é perceber as características formais e sígnicas que eles apresentam nas cenas.

20 Sobre este anjo anunciador, ver: Vicente (2013).

21 Ver: Lumen Gentiun, A bem-aventurada Virgem Maria mãe de Deus no mistério de Cristo e da Igreja. cap. VIII, v. 68 . 
pintura. $^{22} \mathrm{Na}$ ligação das figuras $(\mathrm{M}=$ América, São João Evangelista, Nossa Senhora, São João Batista e Europa; A = Ásia, Cordeiro e África), a quem a Imaculada é intercessora, está o seu monograma, que é reforçado nas cúpulas ilusórias, presentes na extremidade vertical da quadratura. Poderia o pintor ter inserido propositalmente o monograma da Mãe misericordiosa, a marca cristã de Maria Magister?23 (Figura 5).

Esta composição pictórica questiona o tipo de artista que era José Joaquim da Rocha e deixa claro que suas bases estavam vinculadas também ao entendimento do cristianismo e da cientifização das leis tratadísticas. Ele parece ter sido um homem de estudos profundos, e não apenas esquemáticos em traçados e composições de pintura. O esquema subjetivo que utilizou para montar a simbologia desta obra revela alguém que vai além dos estudos técnicos. A mensagem sacra que imprimiu na cenografia, mais precisamente no centro dela, é de que a Santíssima pode aplicar as bênçãos de Deus a quem lhe pede intercessão, ao mesmo tempo em que é aquela que prenuncia o Juízo Final.

[...] depois de elevada ao céu, não abandonou esta missão salvadora, mas, com a sua multiforme intercessão, continua a alcançar-nos os dons da salvação eterna. Cuida, com amor materno, dos irmãos de seu Filho que, entre perigos e angústias, caminham ainda na terra, até chegarem à pátria bem-aventurada. ${ }^{24}$

Com a Trilogia Santa acima dela, Maria se torna a ligação perpétua entre Deus e os homens, medianeira em favor daqueles que querem alcançar os ouvidos do Pai. Sendo mulher e mãe, acolhe-os em favor dos desesperados, em um amor maternal como se tivessem pertencido ao seu ventre, pois dele também saiu um fruto humano que sofreu sua vida terrena, sendo ela testemunha dessa dor até a morte de seu filho. Aceitando sua condição de mãe deste Salvador, foi eleita e escolhida pelo Pai, por isso, sua ligação com Ele. Em nome Dele, do seu Filho, e do Espírito que um dia lhe abençoou para ser a mãe pela humanidade, pode the ser conferido o título de: Nossa Senhora Imaculada Maria Santíssima.

Da Vinci traz uma passagem em seus escritos que muito faz lembrar a estrutura figurista cuidadosamente implantada por Rocha nesta pintura: "Procure

22 Outros elementos presentes na moldura perspéctica reforçam e reafirmam a mensagem cristã que propõe a pintura, mas, como citado, este texto trata apenas da cenografia central. Mais detalhes, ver em Vicente (2011).

23 O artifício aqui identificado (Monograma) foi proposto em parceria com Robson Santana. Ao mostrar a Robson os estudos gráficos da estrutura triangular, que o pintor repete em suas obras, e lhe revelar indícios de que José Joaquim da Rocha poderia usar códigos simbólicos e ocultos para assinar suas pinturas, buscamos algum elemento e nos deparamos com a possibilidade de inserção desse Monograma.

24 Lumen Gentiun, A bem-aventurada Virgem Maria mãe de Deus no mistério de Cristo e da Igreja. cap. VIII, v. 62. 
que a obra se ajuste ao ânimo e à intenção [dos personagens]. Ou seja, quando desenhar uma figura, pense bem em quem ela é e o que pretende que ela faça". (CARREIRA, 2000, p. 116) Dessa forma, embora aqui a pintura da nave da Igreja de Nossa Senhora da Conceição da Praia esteja sendo tratada em sua leitura iconográfica de forma parcial, apenas o quadro recolocado central, os demais elementos que compõem a sua totalidade, presentes na moldura quadraturística, sejam eles geométricos, figuristas, decorativos ou simbólicos, reafirmam a grande cena principal. A Imaculada é a peça chave; é para e sobre ela que tudo converge.

Diante do estudo aqui exposto, pode-se dizer que a mensagem oculta, presente nesta cenografia, é o Juízo Final ainda a ser revelado, tendo, na apoteose da Imaculada e nas figurações que sustentam a sua presença, os elementos necessários para decodificar tal epístola.

\section{A obra e 0 artista: linguagem técnica e sensorial}

A pintura da nave da Igreja de Nossa Senhora da Conceição da Praia é uma absorção de várias escolas quadraturistas, ricas em elementos plásticos e decorativos, desde o seu traçado perspéctico, seguindo uma estrutura mais sistemática presente no Tratado de Andrea Pozzo, à teatralização e efeitos cenográficos presentes nos Bibienas.

José Joaquim da Rocha consegue elaborar uma conexão entre arquitetura virtual e perspectiva plástica, tendo como método basilar o que foi originado na Itália. Adaptado ao ambiente cultural baiano em que estava inserido, repete formulários e esquemas difundidos pelos tratados e gravuras. Dentro dessa repetição, reelaborou novas estruturas e as adaptou às propostas encomendadas, deixando claro seu conhecimento sobre tratadística, matemática, sagradas escrituras e arte litúrgica.

A abordagem pictórica trabalhada por Rocha na referida pintura se enquadra perfeitamente na configuração do propósito catequético da Companhia de Jesus, sobretudo na regra do "Tanto Quanto", do "Princípio Fundamental", inserido nos estudos sobre Inácio de Loyola, de Morsch (1993, p. 73):

[...] as coisas foram criadas para o homem e para ajudá-lo no prosseguimento do fim para o qual fora criado; de modo que usará delas tanto quanto para alcançar o seu fim e tanto quanto se libertará delas, se isso impedir a concretização do mesmo.

Esse mesmo princípio se observa na disposição fundamental de Maria: "Eis aqui a serva do Senhor, cumpra-se em mim segundo a Tua palavra [...]". (BÍBLIA, 2005, Lc, 1: 38) Do mesmo modo, e principalmente, a de Jesus no Horto das Oliveiras: "Pai [...], todavia, não se faça a minha vontade, mas a Tua". 
(BÍBLIA, 2005, 22: 42) Essas passagens que sustentam a proposta catequética e validam a presença desses religiosos em Salvador.

O pintor usou toda a sua experiência artística para traduzir, nesta obra, a relação entre Deus, a Imaculada e os fiéis, ofertando possibilidades simbólicas, ocultas e claras, para que esses últimos pudessem se sentir mais próximos da salvação.

O conjunto pictórico, na sua grandiosa dimensão $\left(600 \mathrm{~m}^{2}\right.$ de área pintada $),{ }^{25}$ representa a espetacularidade do culto, uma das características mais importantes da liturgia barroca. O excesso de ornamentos, curvas, figuras, símbolos e dourados é a cena teatral na sua verdadeira essência; ela nada mais é do que o palco cenográfico projetado no alto. Levando em consideração que Rocha foi também dourador e encarnador, tinha contato com elementos e padronagens da escultura e da talha, transportando seus conhecimentos para suas pinturas de tetos nos ambientes religiosos. Assim, a simulação pictórica dos elementos (volutas, grinaldas, ramalhetes, folhagens, concheados, mísulas, frontões, figuras e personagens religiosos e de cultura etc.), nada mais é do que um retábulo bidimensional (pintado) relocado para o teto.

Curvas, acentuadas e volumosas, e elementos decorativos não estão dispostos ao acaso. São cuidadosamente estudados e colocados no lugar exato. A profusão é existente, mas, ao mesmo tempo, é rítmica e simétrica. Os elementos formais são inseridos sabiamente nas estruturas, revelando aprendizado e experimentação em projeções deste gênero.

Quanto ao efeito de luz e sombra, elemento fundamental para projetar a ilusão na pintura perspéctica e no teatro barroco, Rocha utiliza a contra luz, aproveitando a claridade natural que entra pela grande portada, voltada para o mar. Quando essa luminosidade não mais alcança a obra, ele projeta jogos de sombras, gerando efeitos de volume. Desta forma, se for demarcada uma linha divisória (ilusória) na pintura em sentido horizontal, vê-se, da metade para a entrada, sombras mais claras, enquanto da metade ao arco cruzeiro, sombras mais escuras. Esse jogo composto pelas sombras autentica a falsa arquitetura, pois marca volumetria (colunas e demais elementos que precisam "encorpar") e projeta a espacialidade, que é conseguida entre a projeção da luz natural e da artificial. ${ }^{26}$ “[...] As sombras são de grandíssima utilidade para a perspectiva, pois, sem elas, os corpos opacos e sólidos seriam entendidos erradamente. Erradamente naquilo que contém os contornos em si mesmos [...].” (CARREIRA, 2000, p. 114)

25 A referida medida pode ser encontrada em detalhes sobre suas grandezas, curvatura da abóboda e ápice do centro geométrico em Vicente (2011, p. 829).

26 O desenho da falsa arquitetura adquire caráter realístico a partir de efeitos alcançados com luminosidades e sombreados e com projeções da falsa luz nos locais onde a luz natural, que normalmente entra por portas e janelas, não alcança. Sem esse "jogo de efeitos", a pintura perde esse caráter realístico. 
Raggi (2006, p. 78) aponta que Rocha demonstra capacidade de utilizar a arte e a técnica em favor de uma criação de riqueza e dimensões inusitadas. O relato dessa autora agrupa-se ao que o estudo sobre este artista defende: a de que o pintor possuía aptidões que iam além da plasticidade. (VICENTE, 2011) Desta forma, a pintura da nave da Igreja de Nossa Senhora da Conceição da Praia possui um valor estético de tão grande riqueza, que representa o ápice do trabalho deste artista enquanto pintor decorador. Além disso, o efeito ilusório e construtivo da pintura projetada perspecticamente necessita de um conjunto de técnicas (esboço, demarcações de pontos, linearização com o fio batuto ou outras ações, como alçado do traçado, cartelamento e projeções de figuras, coloração), que, individualmente, não se executa. Nesse aspecto, insere-se uma escola de pintura sob seu domínio e que se torna de fácil percepção pelas repetições das figurações e composições estruturais, que se veem presente em outras pinturas. ${ }^{27}$

José Joaquim da Rocha estava associado ao desenvolvimento da decoração pictórica dentro do universo cultural em que estava enraizado o conhecimento científico e o gosto pela pintura barroca. A pintura de arquiteturas fingidas em si já denota sinal de inovação da tradição científica, e estar imerso nela implica avanço profissional. Ele possivelmente aprendeu a fazer pintura de falsa arquitetura e, depois, retomou e consolidou o aprendizado com alunos e discípulos. Como pintor figurista, registrou sua marca em capelas mores, naves, sacristias e salões nobres. Como quadraturista, traduziu fielmente a concepção pedagógica da nova literatura cristã, sendo capaz de transpor, para os grandes forros, verdadeiras gramáticas litúrgicas envolvidas na arte de persuadir. Ele aplicou o que havia de mais moderno na produção pictórica: a pintura de falsa arquitetura.

A pintura de quadratura, elaborada por este artista decorador, revela conhecimento dos símbolos e ícones cristãos e faz um convite à transcendência material, quando se permite estar diante dela em uma entrega de corpo e alma. Através do visível, do que está diante dos olhos, chegamos ao invisível, ao que se encontra dentro de cada um, em um percurso único e individual. Partilhar a experiência e vivência de interpretar o teto da nave da Igreja de Nossa Senhora da Conceição da Praia é despertar em busca de (auto)verdades. "É necessário um pouco mais que olhos: é necessário olhar”. (LELOUP, 2010, p. 11) Um convite ao encontro com o sagrado e seus mistérios, em que, para vê-los, é necessário um pouco mais do que olhos.

27 A presente autora mantém o estudo sobre este artista e sobre sua produção, esquemática, simbólica e iconográfica, em pinturas de tetos, em nível de doutoramento. 


\section{Referências}

BIBLIA ON LINE. [S. 1.], [20--?]. Disponível em: <www.bibliaonline.com.br>. Acesso em: 2010 .

BÍBLIA. Português. Bíblia Sagrada. Tradução de João Ferreira de Almeida. São Paulo: Imprensa da Fé, 2005.

CANAL, V. L. Fábulas de Velázquez: mitología e historia sagrada enel siglo de Oro. Madrid: Museo Nacional del Prado, 2007.

CASIMIRO, L. A. E. S. A Anunciação do Senhor na pintura quinhentista portuguesa (15001550): análise geométrica, iconográfica e significado iconológico. 2005. 2143 f. Tese (Doutorado em Policopiada) - Faculdade de Letras, Universidade do Porto, Porto, 2005.

CARREIRA, E. (Org.). Os escritos de Leonardo da Vinci sobre a arte da pintura. Brasília: Unb; São Paulo: Imprensa Oficial do Estado, 2000.

LELOUP, J.-I. O icone: uma escola do olhar. Tradução de Martha Gouveia da Cruz. São Paulo: Ed.UNESP, 2006.

MOHR, G. H. Dicionário dos símbolos: imagens e sinais da arte cristã. São Paulo: Paulus, 1994.

MORGADO, F. L. Símbolos do Espírito Santo. Revista Bíblica. [S. 1.], ano 59, n. 345, abr./maio 2013.

MORSCH S, J.; ROCHA, A. Inácio de Loyola. São Paulo: Loyola, 1993.

PIO IX. BulaIneffabilis Deus, [S. 1.], 1854.

PONNAU, D. Figuras de Deus: a bíblia na arte.Tradução de João Moura Junior. São Paulo: Ed. UNESP, 2006.

PROTÁGORAS. Alguns sofistas. [S.1.], [20--?]. Disponível em: <http://www.educ.fc.ul. $\mathrm{pt} /$ docentes/opombo/hfe/momentos/escola/sofistas/protagoras.htm $>$. Acesso em: 16 jun. 2011.

RAGGI, G. Arquiteturas pintadas: a grande decoração barroca bolonhesa e a sua difusão em Portugal e no Brasil no século XVIII. Designio: revista de história e arquitetura e do urbanismo, São Paulo, n. 5, p. 78, mar. 2006.

RÉAU, L. Iconografía del arte cristiano. Barcelona, 2001. (Tomo II, v. 4)

RIBADENEYRA, P. P. Flos sanctorum. Barcelona: en la imprenta de los consortes Sierra, Oliver y Martí, 1790. III Tomo.

SANTOS, A. A. dos. O Brasil sob o manto da Imaculada. São Paulo: Ed. Artpress, 1996.

SECRETARIADO NACIONAL DE LITURGIA. Santos: Assunção da Virgem Santa Maria. [S 1.], [20--]. Disponível em:<http://www.portal.ecclesia.pt/ecclesiaout /liturgia/ liturgia_site/santos/santos_ver.asp?cod_santo=133>. Acesso em: 18 jun. 2011.

SOUZENELLE, A. de. Lesymbolisme du corps humain. [Paris]: Dangles, 1991. 
VICENTE, M. F. M. Anjos anunciadores dos tetos em perspectiva: uma abordagem iconográfica. In: CONGRESSO BRASILEIRO DE ICONOGRAFIA MUSICAL: ABORDAGENS, FRONTEIRASE DESAFIOS, 2., 2013, Salvador. Atas... Salvador: Universidade Federal da Bahia, 2013. p. 59-60.

VICENTE, M. F. M. Antonio Simões Ribeiro, José Joaquim da Rocha e a Escola de pintura quadraturística na Babia: autoria e atribuições. In: O BARROCO em Portugal e no Brasil. Braga: Confraria do Bom Jesus do Monte, 2012. p. 393-407.

VICENTE, M. F. M. A pintura de falsa arquitetura em Salvador: José Joaquim da Rocha (1750-1850). 2011. 1024 f. Dissertação (Mestrado em Artes Visuais) - Escola de Belas Artes, Universidade Federal da Bahia, Salvador, 2011. 